\title{
The Attitudes of Al-Azraq Syrian Refugee Camp Students toward Using "Darsak" Platform in Learning English Language
}

\author{
Hiyam Ahmad Al-Badareen \\ Language Centre, $\mathrm{Al}$ al-Bayt University, Jordan \\ Received March 18, 2021; Revised May 25, 2021; Accepted June 6, 2021
}

\section{Cite This Paper in the following Citation Styles}

(a): [1] Hiyam Ahmad Al-Badareen, "The Attitudes of Al-Azraq Syrian Refugee Camp Students toward Using "Darsak" Platform in Learning English Language," Universal Journal of Educational Research, Vol. 9, No. 7, pp. 1421 - 1429, 2021. DOI: 10.13189/ujer.2021.090708.

(b): Hiyam Ahmad Al-Badareen (2021). The Attitudes of Al-Azraq Syrian Refugee Camp Students toward Using "Darsak" Platform in Learning English Language. Universal Journal of Educational Research, 9(7), 1421 - 1429. DOI: 10.13189/ujer.2021.090708.

Copyright $\bigcirc 2021$ by authors, all rights reserved. Authors agree that this article remains permanently open access under the terms of the Creative Commons Attribution License 4.0 International License

\begin{abstract}
The present study is aimed at investigating the trends of the female students in Al-Azraq Syrian refugee camp towards using "Darsak" platform in learning English language. To achieve the aim of the study, an attitude scale with three dimensions (affective component, perceived usefulness, and perceived control) was prepared and it consisted in its final form of 21 items. It was applied to 110 students of the eighth, ninth and tenth grades from schools in Al-Azraq camp for Syrian refugees in Zarqa Governorate in the Hashemite Kingdom of Jordan during the $1^{\text {st }}$ semester of $2020 / 2021$. The data collected were analyzed using the SPSS statistical program. The mean scores and standard deviations for the attitudes of the students towards "Darsak" platform in learning English were extracted. Based on the analysis, the results revealed that the female students displayed moderate attitudes towards using "Darsak" platform in learning the English language on the questionnaire items as a whole; whereas the students' attitudes on the items of the three dimensions of the questionnaire ranged from weak to moderate levels. The results were discussed and the study ended with recommendations to review and develop "Darsak" platform to achieve the desired educational objectives of using this platform as a digital educational tool.
\end{abstract}

Keywords Attitudes, "Darsak" Platform, Al-Azraq Camp, Syrian Refugee Students, Learning English

\section{Introduction}

Education is considered as a main tool for achieving sustainable development. It is a social and economic leveraging value that changes the lives of individuals and societies for the best. However, this sector, like any other sectors, has been affected by the repercussions imposed by the Corona pandemic. Therefore, it has become necessary to pay attention to the choice of digital education not only for the present time but also for future especially with the rapid change in learning and work patterns. It is also necessary to provide the students with learning materials that employ the latest technology findings to assess the educational outcomes represented in giving the students better opportunities for lifelong learning and self-learning. One shall not forget, the benefits of digital education are in terms of providing flexibility that the students can obtain the information whenever they want without being restricted to time and place, as well as ease of use, and saving of time and effort [1].

In this way, the Jordanian government has not lost sight of the educational aspect for Jordanian students and Syrian refugees alike. Among the aspects of this concern is the interest in instructing English as a foreign language, given that English is a universal language that opens horizons for EFL learners. Gan [2] and Alefesha and Al-Jamal [3] stated that mastering English has many 
benefits as it increases communication skills, develops efficiency and effectiveness in obtaining information through surfing multiple websites, increases employment opportunities in various fields, and so forth.

As such, instructing English to the Syrian refugee students has been a big concern for many resettlement agencies all over the world [4]. Jordan was one of those countries which focused on providing the Syrian refugee students with opportunities to master English. As a neighboring country, Jordan has received nearly the largest number of the Syrian refugees. Francis [5] reported that since the outbreak of political violence in Syria in 2011 , more than 620,000 Syrians have obtained asylum in Jordan. Of these, nearly 84 percent live in host communities. There are about 53,000 Syrian refugees living in Al-Azraq camp for Syrian refugees in Zarqa Governorate. The camp includes four schools distributed in different areas in a manner parallel to the spread of the students to bridge the distances between their homes and schools as close as possible. These schools are monitored by the Jordanian Ministry of Education and provided with Jordanian teachers and Syrian learning assistants.

Again due to the repercussions of the Corona crisis, the Ministry decided to continue educating Syrian students to obtain their right to education and achieve a better life. So, it resorted to digital learning and intensified efforts that resulted in the establishment of "Darsak" platform which is a free Jordanian educational platform for distance learning supervised by the Ministry of Education. "Darsak" platform offers pedagogical lessons to school students from grade one to the second grade of secondary school through video clips regulated and scheduled to be constant with the Jordanian educational curriculum, presented by an eminent group of teachers to help learners sustain their learning and follow-up their educational courses smoothly [6].

Hence, the present research paper is an attempt to investigate the trends of the Syrian refugee students in Al-Azraq camp toward learning English via "Darsak" platform. This is due to the difficult conditions in which this group lives, especially the girls' category. Particularly when it is known that girls in the camp rarely have educational opportunities due to reasons related to society's traditions which state that the fate of any girl is getting married and taking care of her house, husband and children. Other reasons are due to financial reasons, due to the difficult living conditions that prevent girls from completing their studies [7].

\subsection{Problem and Questions of the Study}

In light of the Corona crisis and due to the rapid transmission of COVID-19, the Ministry of Education in Jordan has turned to electronic education to limit the spreading of the virus and maintain students' health. Hence, widespread criticism of the Ministry's actions spread on social media, divided between supporters and opponents. And because the primary concern of the educational process is the students in the first place, it was viewed as important to study the students' attitudes towards online learning based on "Darsak" platform, particularly the perceptions of the Syrian refugee female students at Al-Azraq refugee camp in Jordan during the first semester of the school year 2020/2021. As those students live in difficult daily life conditions, it was important to explore their attitudes and take a look at what their expectations are in such difficult situations.

Accordingly, two research questions were formulated:

1. What are the attitudes of the students toward learning English through "Darsak" platform in Al-Azraq Syrian refugee camp in Jordan?

2. Do students attitudes toward using "Darsak" platform in learning English language differ by grade level?

\subsection{Significance of the Study}

The significance of the study stems from the importance of its topic related to "Darsak" platform and its prominent role in overcoming many different educational difficulties resulting from the conditions imposed by Corona pandemic. It also stems from the attempt to uncover students' trends towards using "Darsak" platform in learning English which reflects the extent of their use of this platform and how beneficial it is. In addition, the significance of this study lies in the importance of the results as it is hoped that decision-makers will benefit from in identifying aspects of using "Darsak" platform in teaching English, so that they might be handled and modified to enrich the e-learning experience in the educational learning system. This study also gains its importance in terms of providing a tool for measuring students' attitudes and contributing to educational literature that may lead to generating further research in the field of disclosure of the attitudes.

\section{Literature Review}

In the momentum of the international and global rush towards providing smart and fast solutions to all the changes that occur in the world of education, scholars conducted studies to research this issue. Unfortunately, the researcher could not find studies that concerned with students' attitudes toward using digital education in learning English except for Janfeshan and Janfeshan [8]. In particular, the researcher could not find studies that tackled using "Darsak" platform in learning English. This is perhaps attributed to the reason that this platform has been established during Corona pandemic to find compensating solutions for the deficiency that could affect the pedagogical system in the Jordanian schools. Therefore, the studies being reviewed in this study are 
addressed with attitudes toward online learning.

Paris [9] studied the perceptions of high school students towards Web-Assisted learning. A questionnaire was applied to fifty-two $10^{\text {th }}$-year students from Adelaide Public Secondary School in Australia. It was discovered that the respondents preferred the web-assisted learning activities to the paper-based learning activities. Besides, it was discovered that there were no significant discrepancies between the attitudes of male and female respondents. The study suggested that the parents should be motivated to use computers to help students study at home with or without teachers' support.

Almarabeh [10] emphasized that e-learning has a high position at the higher educational institutions due to the developments in the technological fields. As such, she examined the perceptions of the undergraduate students at the University of Jordan toward electronic depending on the Technology Acceptance Model. A questionnaire was administered to 180 students of different majors. The findings displayed that the students had good qualifications and high acceptance of the Technology Acceptance Model. They also had the desire for using it in more developmental ways.

Noor-Ul-Amin [11] scrutinized the attitudes of higher secondary school towards the computer. In particular, the study was after specifying whether or not the variables of gender and parents' level of educations have an effect on the students' attitudes towards computer. The sample consisted of 210 students who were randomly chosen from the District of Srinagar (J\&K). To gather information, the researcher utilized "Computer Attitude Scale". Due to the data analysis, the results exhibited that the trends of the students towards computer did not change according to gender. Both boys and girls showed positive trends towards computer. The results also revealed that the parents' level of education, that is, college level, school level and illiterate, had no effect on the students' perceptions, and the students displayed favorable trends toward computer.

Ingeç [12] examined the perceptions toward digital learning among technical and vocational high school students relevant to specific variables. The sample comprised of 119 male and female respondents. Information was gathered through a questionnaire that consisted of two parts: the first part contained personal and demographic data and the second part contained statements about the attitudes towards e-learning. After analyzing the results, it was found that there were no statistically significant discrepancies concerning gender, experience in handling with computer, the number of times of using computer and the manner of stimulation. The analysis also revealed that there was an impact of the studying and learning methods on the attitudes towards e-learning.

Malkawi, Nawafleh, and Alsaqqar [13] investigated the students' and teachers' attitudes towards electronic learning in the higher primary schools in Jordan, and the effect of some variables related to the teachers and students concerning their attitudes towards e-learning. To accomplish the aims of the study, a questionnaire was designed by the researchers. The sample involved 139 teachers and 359 male and female students in the Second Irbid Education Directorate. The study disclosed that the teachers showed positive trends towards electronic learning while the students showed moderate positive attitudes. The researchers recommended that the teachers' and students' attitudes toward e-learning should be promoted and encouraged via introducing programs and tasks that are congruent with the curriculum.

Due to the tremendous development in the domain of information technology and the efficacy of this progress in many sectors, particularly in education, Al-Momani [14] compared public and private Jordanian universities by examining the factors that influence student attitudes towards electronic learning. The study sample included 489 students from the University of Jordan as a public university and Zarqa University as a private one. The study framework was built based on the Technology Acceptance Model. Accordingly, a questionnaire was distributed to students from both universities. After analyzing the results, it was discovered that students' attitudes towards digital learning were positive with high percentage.

Hamadin [14] examined the attitudes of the school principals towards integrating e-learning in the instructional process as it is necessary for achieving their administrative jobs. The sample consisted of 250 school head teachers of public schools from Al-Karak Governorate in Jordan. To gather information, a survey was developed by the researcher. The results showed the school principals had positive attitudes towards e-learning. However, they needed training in some applications and further technological resources that help them in administering their work.

In their study, Bardakci, Arslan, and Can [16] addressed the perceptions of high school students regarding their experience with e-learning in the light of cultural regards. To collect data, a questionnaire was used that included eight open-ended questions along with demographic information. The number of learners who participated in the study was 30 students. The results uncovered that most students made use of the discussion activities that were conducted via the Internet and added further suggestions. The students found that they felt secure in expressing their opinion freely in the absence of their peers and teacher physical presence. They revealed that one of the main barriers was the lack of self-confidence in sharing and showing others what they wrote on the posts. In comparison with classroom discussions, it turned out that online discussions were more flexible in expressing opinions without any pressure.

Janefshan and Janefshan [8] inspected the impact of 
Otus application on teaching English as a foreign language for high school students in Iran. The researchers also inspected the trends of the learners towards this application in mastering English. The respondents were 50 male students conveniently selected and distributed to experimental and control groups. Lessons and assignments were prepared based on Otus application for the experimental group. Moreover, a questionnaire was designed to uncover the students' attitudes toward this application. The findings disclosed that the students' performance improved comparing with the control group which was instructed English in the traditional way, i.e. did not receive digital education. In addition, the students had positive attitudes toward using Otus in learning English.

Reviewing the previous studies, it was found that the studies which were conducted on the students' attitudes were few. Most of the studies found in Jordan focused on the higher education and less on the school students' attitudes. Therefore, this study can add to the literature in this field. Besides, there were only two studies which handled the Syrian refugees in Jordan [3] and [17]. However, these two studies did not handle the perceptions of the students toward "Darsak" platform, or digital learning in general. Al-Badou, Al-Jamal and Sa'di [17] tackled the impact of using semantic mapping on teaching vocabulary to the refugees in Alzaatari camp while Alefesha and Al-Jamal [3] handled the challenges that face the Syrian refugees in EFL learning. Another dissimilarity is that the previous studies differed from the present study in the location, population, and samples. None of the previous studies handled the Syrian refugees in Al-Azraq Refugee Camp.

\section{Method}

\subsection{Design of the Study}

The study followed a descriptive design in which the researcher describes the phenomenon of using "Darsak" platform as one of the digital education forms in learning English in Jordan. Besides, the study tackles the attitudes of students towards using "Darsak" platform in learning English in terms of the grade variable. An attitudinal survey was designed and used for this purpose.

\subsection{Participants of the Study}

The participants were 110 students conveniently selected from schools in Al-Azraq Refugee Camp in the first semester of $2020 / 2021$. Thirty-five percent $(n=38)$ were from eighth grade, 23 percent $(n=25)$ were ninth-grade students, and 42 percent $(n=42)$ were tenth grade students. Ninety-three percent $(n=102)$ of the students do not have computers, and 73 percent $(n=80)$ do not have mobiles.
Table 1. Sample Distribution

\begin{tabular}{lccc}
\hline Variable & & N & Percentage \\
\hline \multirow{2}{*}{ Grade Level } & Eighth & 38 & 35 \\
\cline { 2 - 4 } & Ninth & 25 & 23 \\
\cline { 2 - 4 } & Tenth & 47 & 42 \\
\hline $\begin{array}{l}\text { Do you have } \\
\text { computer? }\end{array}$ & Yes & 8 & 7 \\
\hline Do you have a mobile? & No & 102 & 93 \\
\cline { 2 - 4 } & Yes & 30 & 27 \\
\hline
\end{tabular}

\subsection{Instrument of the Study}

To collect information relevant to the attitudes of the students toward using "Darsak" platform in learning English, a questionnaire was designed based on Technology Acceptance Model [18] and studies in the field [13], [19] and [20]. The items of the Attitudinal Questionnaire (AQ) comprised of 21 items distributed into three subscales, namely: Perceived Usefulness (PU: 6 items), Perceived Control (PC: 5 items), and Affective Component (AC: 10 items). The students were asked to express their attitudes on the questionnaire based on Likert scale ranging from (1: Strongly disagree) to (5: Strongly agree).

\subsubsection{Content validity}

For the content validity of the attitudinal questionnaire, five experts evaluated the 34 items in terms of language clarity and relevance to attitudes toward using "Darsak" Platform in learning English. Some items were reformulated to achieve a better certainty of understanding and others were dropped out so the final total items were 21. Also, words that seemed too vague were replaced by synonyms that are easy to understand.

\subsubsection{Construct validity}

Pearson correlation coefficients between the item score and the total score of its domain extracted and four items deleted ( $r<0.19$ or negative). As such, Pearson correlation coefficients for the remaining items ranged from: .67 to .85 for affective component, .83 to .85 for perceived usefulness, and .44 to .77 for perceived control. All the correlation coefficients were statistically significant $(P<$ 0.01 ) and higher than .35 , indicating an acceptable degree of internal consistency.

Furthermore, corrected item-total correlation between the item score and the total score of its domain was calculated. This correlation ranged from .52 to .72 for affective component, .77 to .81 perceived usefulness, and .44 to .64 for perceived control, All the correlation coefficients are statistically significant $(P<0.01)$ and higher than 20 indicating an acceptable degree of internal 
consistency.

Table 2 illustrates the regression estimates, standard errors (SE), Beta values, the $t$ values of the items, and the significance level. As it is shown in table 2, all parameters (paths) were regarded to be significant which indicated that each item contributes significantly to the associated factor.

\subsubsection{Reliability}

To achieve the reliability of the instrument, the questionnaire was piloted at a sample of 67 students out of the main participants of the study. The reliability of the attitudinal questionnaire was evaluated using the Cronbach Alpha approach. Cronbach alpha coefficients for the affective component, perceived usefulness, and perceived control were $0.86,0.91$, and 0.83 , respectively. Cronbach alpha coefficient for the entire scale was .87 showing that the scale was reliable for measuring the students' attitudes.

\section{Results}

In order to find answers to the first research question "What are the students' attitudes towards learning English through "Darsak" platform in Al-Azraq Syrian refugee camp in Jordan?", means and standard deviations for each item and AQ components were extracted. Ranges of agreement with the attributions on the AQ were determined by using the following rubric: the interval of 1 to less than 2.44 showed a low level, 2.44 to less than 3.66 interval showed a moderate level, and 3.66 to 5 interval showed high level.

Based on data analysis, the results uncovered that the mean scores of the students' attitudes toward using "Darsak" platform in learning English ranged from 2.17 to 3.06 for AC items. This indicated that students reported low to moderate level of attitudes toward using "Darsak" platform in learning English. Besides, the mean score of AC is 2.62 displaying moderate level of the students' attitudes. The results are shown in Table 3.

Table 2. Regression estimates, standard errors, Beta values, and the $t$ values (C.R.) of the items, and the level of significant

\begin{tabular}{|c|c|c|c|c|c|c|c|}
\hline & Path & & Estimate & S.E. & Beta & C.R. & $P$ value \\
\hline $\mathrm{AC}$ & $\rightarrow$ & A6 & 1.000 & & .759 & & \\
\hline $\mathrm{AC}$ & $\rightarrow$ & A5 & 1.108 & .105 & .929 & 10.529 & 0.00 \\
\hline $\mathrm{AC}$ & $\Rightarrow$ & A4 & .878 & .117 & .695 & 7.507 & 0.00 \\
\hline $\mathrm{AC}$ & $\rightarrow$ & $\mathrm{A} 2$ & .694 & .108 & .607 & 6.449 & 0.00 \\
\hline $\mathrm{AC}$ & 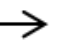 & $\mathrm{A} 1$ & .882 & .114 & .712 & 7.715 & 0.00 \\
\hline PU & & U6 & 1.000 & & .804 & & \\
\hline PU & & U5 & .983 & .097 & .830 & 10.088 & 0.00 \\
\hline PU & & $\mathrm{U} 4$ & 1.002 & .098 & .837 & 10.208 & 0.00 \\
\hline PU & & U3 & 1.035 & .100 & .844 & 10.322 & 0.00 \\
\hline $\mathrm{PU}$ & 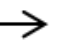 & U1 & 1.082 & .111 & .809 & 9.719 & 0.00 \\
\hline $\mathrm{PC}$ & & $\mathrm{C} 8$ & 1.000 & & .607 & & \\
\hline $\mathrm{PC}$ & & $\mathrm{C} 7$ & 1.125 & .193 & .708 & 5.827 & 0.00 \\
\hline $\mathrm{PC}$ & 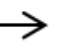 & C6 & .952 & .180 & .619 & 5.281 & 0.00 \\
\hline $\mathrm{PC}$ & & $\mathrm{C} 5$ & 1.152 & .200 & .695 & 5.750 & 0.00 \\
\hline $\mathrm{PC}$ & 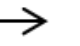 & $\mathrm{C} 4$ & 1.095 & .194 & .675 & 5.631 & 0.00 \\
\hline $\mathrm{PC}$ & $\rightarrow$ & $\mathrm{C} 2$ & .868 & .180 & .553 & 4.834 & 0.00 \\
\hline $\mathrm{PC}$ & $\rightarrow$ & $\mathrm{C} 1$ & .972 & .191 & .590 & 5.090 & 0.00 \\
\hline
\end{tabular}

Table 3. Means and standard deviation for AC subscale

\begin{tabular}{|c|c|c|c|}
\hline Item Code & Item & Mean & Standard Deviation \\
\hline A1 & $\begin{array}{l}\text { I liked learning English through "Darsak" platform because the time of } \\
\text { English classes was flexible and convenient }\end{array}$ & 3.06 & 1.20 \\
\hline A2 & $\begin{array}{l}\text { I enjoyed learning English through "Darsak" platform more than learning } \\
\text { in the classroom. }\end{array}$ & 2.17 & 1.11 \\
\hline A4 & $\begin{array}{l}\text { I didn't like learning English through "Darsak" platform because it cost } \\
\text { more than face-to-face learning. }\end{array}$ & 2.35 & 1.22 \\
\hline A5 & $\begin{array}{l}\text { I would like to continue learning English through "Darsak" platform in } \\
\text { the future. }\end{array}$ & 2.55 & 1.15 \\
\hline \multirow[t]{2}{*}{ A6 } & Learning through "Darsak" platform encouraged me to learn English. & 2.74 & 1.28 \\
\hline & Affective component & 2.62 & .84 \\
\hline
\end{tabular}


Concerning the PU items, the mean scores ranged from 2.38 to 2.55 . With this in mind, students reported low levels of attitudes toward using "Darsak" platform in learning English language. The mean score of PU is 2.50 indicating moderate level of the students' attitudes. The results are revealed in Table 4.

As for the PC items of the attitudinal questionnaire, the mean scores ranged from 2.31 to 3.49. As such, the students reported low to moderate level of attitudes toward using "Darsak" platform in learning English. The mean score of PC is 2.83 revealing moderate level of the students' attitudes. The results are uncovered in Table 5.

To answer the second question "Do students' attitudes toward using "Darsak" platform in learning English language differ by grade level?", a multivariate analysis of variance (one-way MANOVA) was conducted to assess if there were differences between the three grades on a linear combination of the three components of students' attitudes toward using "Darsak" platform in learning English. A remarkable difference was discovered as the results disclosed that Wilk's Lambda $=.847, F=3.03$, eta square $=0.08, p=0.0$. As such, the grade level statistically and significantly impact the linear combination of the 3 dimensions of students' perceptions toward using "Darsak" platform in learning English. Follow up univariate ANOVAs were calculated to scrutinize the effect of the grade level on each dimension of student's attitude. It was pinpointed that there were no remarkable statistical effects of the grade level on: $\mathrm{AC}(\mathrm{F}(2,107)=0.692 . \mathrm{P}=0.503)$, $\mathrm{PU}$ $(\mathrm{F}(2,107)=2.122$. $\mathrm{P}=0.125)$, and $\mathrm{PC}(\mathrm{F}(2,107)=1.907$. $\mathrm{P}=0.153)$. The results are illustrated in Table 6 .

Table 4. Means and standard deviation for PU subscale

\begin{tabular}{llcc}
\hline Item Code & Item & Mean & Standard Deviation \\
\hline U1 & $\begin{array}{l}\text { I could understand English lessons through "Darsk" platform in the same degree } \\
\text { as face-to-face learning }\end{array}$ & 2.32 & 1.30 \\
\hline U3 & I think "Darsak" platform is suitable for learning English. & 2.40 & 1.19 \\
\hline U4 & $\begin{array}{l}\text { Learning English through "Darsak" platform was beneficial to be well qualified } \\
\text { in the English language. }\end{array}$ & 2.55 & 1.16 \\
\hline U5 & I feel I became good in English because of "Darsak" platform. & 2.38 & 1.15 \\
\hline U6 & $\begin{array}{l}\text { I became more interactive in the English lesson with learning through "Darsak" } \\
\text { platform }\end{array}$ & 2.43 & 1.20 \\
\hline & Perceived usefulness component & $\mathbf{2 . 5 0}$ & $\mathbf{. 9 3}$ \\
\hline
\end{tabular}

Table 5. Means and standard deviation for PC subscale

\begin{tabular}{llcc}
\hline Item Code & Item & Mean & Standard Deviation \\
\hline $\mathrm{C} 1$ & $\begin{array}{l}\text { There were no technical problems concerning internet connections through } \\
\text { learning English via "Darsak" platform }\end{array}$ & 2.31 & 1.28 \\
\hline $\mathrm{C} 2$ & $\begin{array}{l}\text { I could participate in the English lessons through "Darsak" platform in a way } \\
\text { better than in the school room. }\end{array}$ & 2.36 & 1.22 \\
\hline $\mathrm{C} 4$ & $\begin{array}{l}\text { It was easy to use "Darsak" platform for taking the English language tests and } \\
\text { submitting assignments }\end{array}$ & 3.13 & 1.26 \\
\hline $\mathrm{C} 5$ & $\begin{array}{l}\text { I could ask my English teacher and get feedback through "Darsak" platform just } \\
\text { as in the classroom. }\end{array}$ & 2.62 & 1.29 \\
\hline $\mathrm{C} 6$ & $\begin{array}{l}\text { It was very easy to do electronic actions such as: file downloading, chatting, and } \\
\text { posting messages via "Darsak" platform. }\end{array}$ & 2.95 & 1.19 \\
\hline $\mathrm{C} 7$ & $\begin{array}{l}\text { Learning English through "Darsak" platform saved time and effort as I could } \\
\text { find the information very fast and easily }\end{array}$ & 2.84 & 1.23 \\
\hline $\mathrm{C} 8$ & $\begin{array}{l}\text { I feel that I am skillful in using the technological devices such as mobile and } \\
\text { laptops which 9helped me in using "Darsak" platform in learning English }\end{array}$ & 3.49 & 1.28 \\
\hline & Perceived control & $\mathbf{2 . 8 3}$ & $\mathbf{. 6 8}$ \\
\hline
\end{tabular}

Table 6. Effects of grade level on attitudes toward using "Darsak" platform in learning English

\begin{tabular}{|c|c|c|c|c|c|c|}
\hline Source & Dependent variable & Sum of Squares & df & Mean Square & $\mathbf{F}$ & Sig. \\
\hline \multirow{3}{*}{ Grade level (class) } & $\mathrm{AC}$ & .981 & 2 & .491 & .692 & .503 \\
\hline & PU & 3.633 & 2 & 1.817 & 2.122 & .125 \\
\hline & $\mathrm{PC}$ & 1.782 & 2 & .891 & 1.907 & .153 \\
\hline \multirow{3}{*}{ Error } & $\mathrm{AC}$ & 75.882 & 107 & .709 & & \\
\hline & $\mathrm{PU}$ & 91.616 & 107 & .856 & & \\
\hline & $\mathrm{PC}$ & 49.989 & 107 & .467 & & \\
\hline \multirow{3}{*}{ Total } & $\mathrm{AC}$ & 830.028 & 110 & & & \\
\hline & PU & 783.583 & 110 & & & \\
\hline & $\mathrm{PC}$ & 933.568 & 110 & & & \\
\hline
\end{tabular}




\section{Discussion}

The results of the first research question "What are the students' attitudes towards learning English through "Darsak" platform in Al-Azraq Syrian refugee camp in Jordan?", revealed that the students at Al-Azraq refugee camp showed moderate level of attitudes toward the use of "Darsak" platform in learning English on three components of the AQ (affective component, perceived control, and perceived usefulness). As there are no studies that could be found on "Darsak" platform, the findings of the present study might be considered as relevant to studies concerned with online learning or digital education. As such, the results go alignment with Malkawi et al [13] who pointed out that the students' attitudes toward electronic learning were moderate due to their feeling that e-learning lacks interaction with teachers and peers, and underestimates the role of teacher and the textbook in the instructional process.

A further interpretation might be related to the truth that students do not access into the platform. As reported by the teachers in Al-Azraq camp, students specially girls have no interest in education, particularly English. This is due to the harsh circumstances where the refugees live in the camp. This is congruent with [3], [4] and [21] who reported that the Syrian refugees live in miserable conditions where their main concern is how to find shelter, food, and clothing. They revealed that there are obstacles in learning English in the Syrian refugee camps due to several reasons such as English is not their mother tongue language, the students live in a completely new environment of education, and they are not familiar with the teachers and peer students. Besides Karam [22] stated that the bulk of the Syrian refugees are psychologically upset and unfit because of what they had experienced due to the violence in Syria. Saavedra and Bousquet [7] uncovered that conditions such as poverty, lack of technological devices, being away for a long time from school because of the conflict contribute to poor education of students coming from countries of political conflict and violence.

Another explanation for the findings of the current study is that it was difficult for the Syrian refugee girls to return to school and they had to quit school early to be committed to household works. According to Ahdath [23], the percentage of girls who said that they did not follow "Darsak" platform because they were busy with other tasks seemed to be consistent with reports of civil society organizations, warning that the closure of schools has increased the domestic and care tasks incumbent on girls in their families, which is an obstacle to education.

Moreover, the findings displayed that there was no chance for students to participate and interact with their teachers and peer students. Besides, the students revealed that they didn't like "Darsak" platform or enjoyed using it, and they did not have the desire to continue using this platform in future. These results contradict several studies that were conducted on digital education e.g. [10], [11], [14], and [16] which found that the students showed positive attitudes toward using digital learning. This is because the students in the refugee camps did have the same chances as other students at the universities or private schools which provide their students with platforms like Microsoft teams, in which the students can interact and communicate with their teachers. As it was cleared earlier in this study, the people in the refugee camps live in miserable situations that make them not interested in learning English because they have other issues to concern about. This is congruent with Aduwa-Ogiegbaen and Iyamu [24] who pinpointed that living in poor, noisy environment is one of the elements that may affect learning English.

The refugee female students also did not show high level of attitudes toward learning English through "Darsak" platform because there were technical problems that hindered their learning or logging in the platform. A survey of the United Nations Children's Fund "UNICEF" uncovered that $26.2 \%$ of females indicated that they did not log in "Darsak" platform due to the lack of availability of the Internet or running out of the Internet package, or lack of the technological devices [23]. Students in this study reported that they do not own mobiles or computers. When their teachers were asked how the students use "Darsak" platform, they said some students used their parents' mobiles, some did not log in the platform, and unfortunately some students did not hear of "Darsak" platform.

As for the second research question "Do students attitudes toward using "Darsak" platform in learning English language differ by grade level?", the results displayed that the attitudes of the students were moderate. This is due to the reason that these female students live in the same conditions as they are all refugees, study in the same schools, have the same teachers, and use the same platform in learning English. This is congruent with Malkawi et al [13] who stated that the students who have the same conditions and receive the same type of education show the same attitudes toward learning.

\section{Conclusions and Recommendations}

The study found that the students had moderate attitudes toward using "Darsak" platform in learning English which was congruent with Malkawi et al [13]. Moreover, it was disclosed that the students could not follow "Darsak" platform in learning English, they did not enjoy learning English through "Darsak" platform and they had no desire to continue using this platform in future. These findings were not in agreement with studies in the field as there are many reasons represented in the poor conditions, capabilities and services available in the 
camp. Jordan was one of the first countries that responded to the Corona pandemic and imposed lockdown to maintain the people's health safe. At the same time, it showed interest in sustaining education so it tried its best and provided "Darsak" platform free for all Jordanian and refugee students as well. However, these efforts are required to be reviewed and developed to empower the students with good education.

Accordingly, it is recommended that

- the government should provide all physical and technological equipment essential to afford chances for both instructors and students to sustain education in the currently hard situations.

- international organizations should be committed to its role in supporting the students in the refugee camps and providing them with technological devices, such as laptops or tablets to help them continue their learning.

- the concerned authorities should check the infrastructure and internet availability in the refugee camps as these are important in the online learning.

- the Ministry of Education should find ways to check the outcomes of using "Darsak" platform in teaching English in Al-Azraq camp and other areas.

- a further research is needed to inspect the impact of using Darsak platform in instructing English and compare it with other platforms.

- conducting similar studies in wider educational areas to be able to generalize the findings of the study.

\section{REFERENCES}

[1] Khan, M.A.; Vivek; Nabi, M.K.; Khojah, M.; \& Tahir, M. "Students' Perception towards E-Learning during COVID-19 Pandemic in India: An Empirical Study", Sustainability, vol. 13, n. 57, pp.1-14, 2021. https://dx.doi.org/10.3390/su13010057

[2] Gan, Z. "Learning to Teach English Language in the Practicum: What Challenges do Non-Native ESL Student Teachers Face?", Australian Journal of Teacher Education, vol. 38, n. 3, 2013. https://files.eric.ed.gov/fulltext/EJ10129 44.pdf

[3] Alefesha, H. \& Al-Jamal, D. 'Syrian Refugees' Challenges and Problems of Learning and Teaching English as a Foreign Language (EFL): Jordan as an Example" Journal of Ethnic and Cultural Studies, vol. 6, n. 1, pp.117-129, 2019.

[4] Al Hariri, B. "Teaching ESL to Syrian Refugees: Problems and Challenges". Published Master Thesis, University of Toledo, Ohio. 2018.https://etd.ohiolink.edu/apexprod/rws e $\mathrm{td} /$ send_file

[5] Francis, A. "Jordan's Refugee Crisis", 2015. Online available from https://carnegie-mec.org/2015/09/21/ar-pub61296

[6] Jordanian Darasak Platform for Distance Education. Online available from https://sotor.com

[7] Saavedra, J. \& Bousquet, F. "Committing to Learning for Every Child, Despite Conflict and Crisis", https://blogs.worldbank.org/dev4peace/committing-learning -every-child-despite-conflict-and-crisis

[8] Janfeshan, K. \& Janfeshan, M.M. "The Effect of Otus Social Educational Network on English Achievement and Attitudes of Iranian High School EFL Learners". Cogent Arts \& Humanities, vol. 8, n. 1, pp. 1-20, 2021.

[9] Paris, P.G. (2004). "E-Learning: A study on Secondary Students' Attitudes towards Online Web Assisted Learning", International Education Journal, vol. 5, n. 1, pp. 98-112, 2004.

[10] Almarabeh, T. (2014). "Students' Perceptions of E-learning at the University of Jordan", International Journal of Emerging Technologies in Learning (iJET), vol. 9, n.3, pp. 31-35, 2014.

[11] Noor-Ul-Amin, S. "Computer Attitude among Higher Secondary School Students in District Srinagar (J\&K): A Study", Academia Journal of Educational Research, vol. 2, n. 4, pp. 79-86, 2014. DOI: http://dx.doi.org/10.15413/ajer.201 3.0025

[12] Ingeç, S. K. “Investigation of Students' Attitudes towards E-learning in Terms of Different Variables - A Case Study in a Technical and Vocational High School for Girls", Educational Research and Reviews, vol. 10, n.1, pp. 81-91, 2015.

[13] Malkawy, A., Nawafleh, W., \& Alsaqqar, M. (2015). Students and Teachers Attitudes towards E-learning in Higher Primary Schools in Jordan", An-Najah University Journal for Research - B (Humanities), vol. 29, n. 2, pp. 1-39, 2015.

[14] Al-Momani, M. M. (2017). "Evaluating Students' Attitude Toward the Use of E-Learning: A Comparative Study Between a Private and Public Universities in Jordan", Information and Knowledge Management, vol. 7, n. 1, pp. 17-24, 2017.

[15] Hamadin, K. "Implementation E-learning Among Jordanian School's Management", Journal of Education and Practice, vol.8, n. 11, pp. 79-87, 2017.

[16] Bardakci, S., Arslan, O., \& Can, Y. "Online Learning and High School Students: A Cultural Perspective", Turkish Online Journal of Distance Education-TOJDE, vol. 19, n. 4, pp. 126-146, 2018.

[17] Al-Badou, H., Al-Jamal, D. \& Sa'di, I. "Language for Resilience: Semantic Mapping and Syrian Refugees", Journal of Ethnic and Cultural Studies, vol. 7, n. 1, pp. 56-69, 2020. http://dx.doi.org/10.29333/ejecs/334

[18] Davis, F. D. "Perceived Usefulness, Perceived Ease of Use, and User Acceptance of Information Technology", MIS Quarterly, vol. 13, n. 3, 319 - 339, 1989.

[19] Abedalaziz, N., Jamaluddin, S., \& Leng, C. H. "Measuring Attitudes toward Computer and Internet Usage among Postgraduate Students in Malaysia”, TOJET: The Turkish Online Journal of Educational Technology, vol. 12, n.12, 2013. https://www.researchgate.net/publication/281090107

[20] Abedalaziz, N., Muaidi, H. "Attitudes towards 
Internet-Based Distance Education among Academic Staff of Malaysian Universities", International Journal of Sustainable Development, vol. 5, n. 1, 2012. http://www.ssrn.com/link/ OIDA-Intl-Journal-Sustainable-Dev.html

[21] Baynham, M. "Agency and Contingency in the Language Learning of Refugees and Asylum Seekers", Linguistics and Education, vol. 17, n. 1, pp. 24-39, 2006.

[22] Karam, F. J., Kibler, A. K., \& Yoder, P. J. "Because Even us, Arabs, now Speak English: Syrian Refugee Teachers'
Investment in English as a Foreign Language". International Journal of Intercultural Relations, vol. 60, pp. 169-182, 2017.

[23] Ahdath 24. " $32 \%$ of the Students Do Not Log in the Darsak Platform". Online available from https:/www.ahdath24.co $\mathrm{m} /$ article/242361

[24] Aduwa-Ogiegbaen, S. E. \& Iyamu, E. O. S. "Factors Affecting Quality of English Language Teaching and Learning in Secondary Schools in Nigeria", College Student Journal, vol. 40, n. 3, pp. 495 - 504, 2006. 